\title{
Pseudomembranous trigonitis of the bladder: hormonal aetiology
}

\author{
T J STEPHENSON, L HENRY, S C HARRIS, D D GIRI, M FOX, * J C E UNDERWOOD \\ From the Department of Pathology, University of Sheffield Medical School, and the *Department of Urology, \\ Royal Hallamshire Hospital, Sheffield
}

SUMMARY Fourteen formalin fixed and paraffin wax embedded biopsy specimens from 10 women (age range 34-68) presenting with pseudomembranous trigonitis were studied using a combination of anti-oestrogen receptor monoclonal antibodies in an avidin-biotin immunoperoxidase technique. All epithelial areas showing vaginal metaplasia exhibited staining confined to the nucleus in the basal and parabasal layers of the squamous epithelium while no staining was encountered in adjacent trigonal transitional epithelium included in nine of the biopsy specimens.

The selective expression of nuclear oestrogen receptor in trigonal epithelium affected by vaginal metaplasia in a distribution similar to that reported in vaginal epithelium by other workers lends further support to oestrogen mediated aetiology in this condition and is consistent with an embryological derivation of the trigone, distinct from that of the rest of the bladder.

Pseudomembranous trigonitis, a recognised cause of the "urethral syndrome", is characterised by urgency and frequency of micturation. A characteristic lesion of the bladder trigone is seen on cytoscopy. Biopsy specimens show squamous metaplasia of the trigonal epithelium closely resembling vaginal squamous epithelium. The epithelial cells are vacuolated and contain abundant glycogen, while the lamina propria shows noticeable venous dilatation associated with oedema. ${ }^{1}$

Originally described by Heymann as "trigonal cystitis", ${ }^{2}$ the lesion has since been termed pseudomembranous trigonitis, granular trigonitis, urethrotrigonitis, and squamous or vaginal metaplasia of the trigonal epithelium. The lesion is almost exclusively found in women, although in one study of 31 cases $^{1}$ three were in men, one of whom was receiving oestrogen for carcinoma of the prostate.

While some reports have considered vaginal metaplasia of the trigone to be an adaptive response to inflammation of the bladder, ${ }^{3-5}$ other studies have suggested that it develops under the hormonal influence of oestrogens. ${ }^{67}$ In particular, Tyler correlated variations in the histological appearance of the vaginal metaplasia with phases of the menstrual cycle. ${ }^{8}$ Although no study of the presence of oestrogen receptor has been reported in pseudomembranous

Accepted for publication 20 April 1989 trigonitis, nuclear oestrogen receptors, demonstrable by both radioligand ${ }^{9}$ and immunohistochemical tech niques, ${ }^{10} 11$ have been correlated with cyclical oestrogen? responsiveness in the female genital tract.

The availability of rat monoclonal antibodies to nuclear oestrogen receptor ${ }^{1213}$ has facilitated our development of a sensitive avidin-biotin immunoperoxidase technique for detection of their binding to routinely fixed and processed tissues. For the first time, this has allowed the presence of nuclear oestrogen receptor proteins to be shown in archival tissue from this relatively rare condition and for their expression to be compared with that seen in unaffected trigonal transitional epithelium.

\section{Material and methods}

Archival tissue fixed in neutral $10 \%$ formalin and processed to paraffin wax was available from 14 biopsy specimens from 10 women (age range 34-68) undergoing cystoscopy for investigation of the "urethral syndrome". The urine had previously proved normal on routine testing and was sterile. Clinical examination yielded negative results. The biopsy specimens had been selected from the abnormal greyish and raised areas of trigonal mucosa with serpiginous borders typical of pseudomembranous trigonitis and from the adjacent cystoscopically unremarkable trigonal mucosa. Histologically normal 
trigonal transitional mucosa, included in nine of the biopsy sets, acted as control epithelium for comparison with that showing vaginal metaplasia, while two samples of vaginal squamous epithelium and three of the endometrial functionalis, known to express nuclear oestrogen receptor protein, " were included as positive controls.

Five micron sections brought to water were optimally trypsinised (usually five to 30 minutes) by titration using a standard protocol. They were given five two minute washes in $0.05 \mathrm{M}$ Tris- $\mathrm{HCl}(\mathrm{pH} \mathrm{7.2)}$. Sections were then covered with a combination of antioestrogen receptor antibodies in $0.05 \mathrm{M}$ Tris- $\mathrm{HCl}(\mathrm{pH}$ 8.0) comprising $\mathrm{H} 222$ antibody $15 \mu \mathrm{g} / \mathrm{ml}$ (Abbott Laboratories, Chicago) together with D75 and D547 antibodies $10 \mu \mathrm{g} / \mathrm{ml}$ each (generously donated by $\mathrm{Dr}$ GL Greene, Ben May Cancer Research Laboratories, Chicago). Sections were incubated at room temperature for 18 hours in a humid chamber. After a further five two minute washes in Tris- $\mathrm{HCl}$ sections were given a secondary incubation with biotinylated antirat IgG (whole molecule, $0.6 \mu \mathrm{g} / \mathrm{ml}$; Sigma) at $1 / 16$ in $0.05 \mathrm{M}$ Tris- $\mathrm{HCl}(\mathrm{pH} \mathrm{7.2)}$ at room temperature for 60 minutes. Following a further five two minute washes in Tris- $\mathrm{HCl}$ the tertiary incubation was with an avidinbiotin PAP romplex (Vectastain ABC reagent, Vector Laboratories), freshly prepared. Incubation was at room temperature for 60 minutes. Sections were again washed five times in Tris- $\mathrm{HCl}$ and bound peroxidase was shown by a standard diaminobenzidine reaction with a very light counterstain of Harris's haematoxylin.

\section{Results}

All 14 biopsy specimens showed areas of keratinising squamous epithelium on routine staining (fig 1) with underlying oedema and venous dilatation in the lamina propria. The epithelial cells showed cytoplasmic vacuolation, which in a previous descriptive study of pseudomembranous trigonitis ${ }^{1}$ has been shown to be due to glycogen accumulation. In nine biopsy specimens, unaffected trigonal transitional epithelium was included (fig 1).

In areas of vaginal metaplastic epithelium, immunohistochemistry showed oestrogen receptor protein

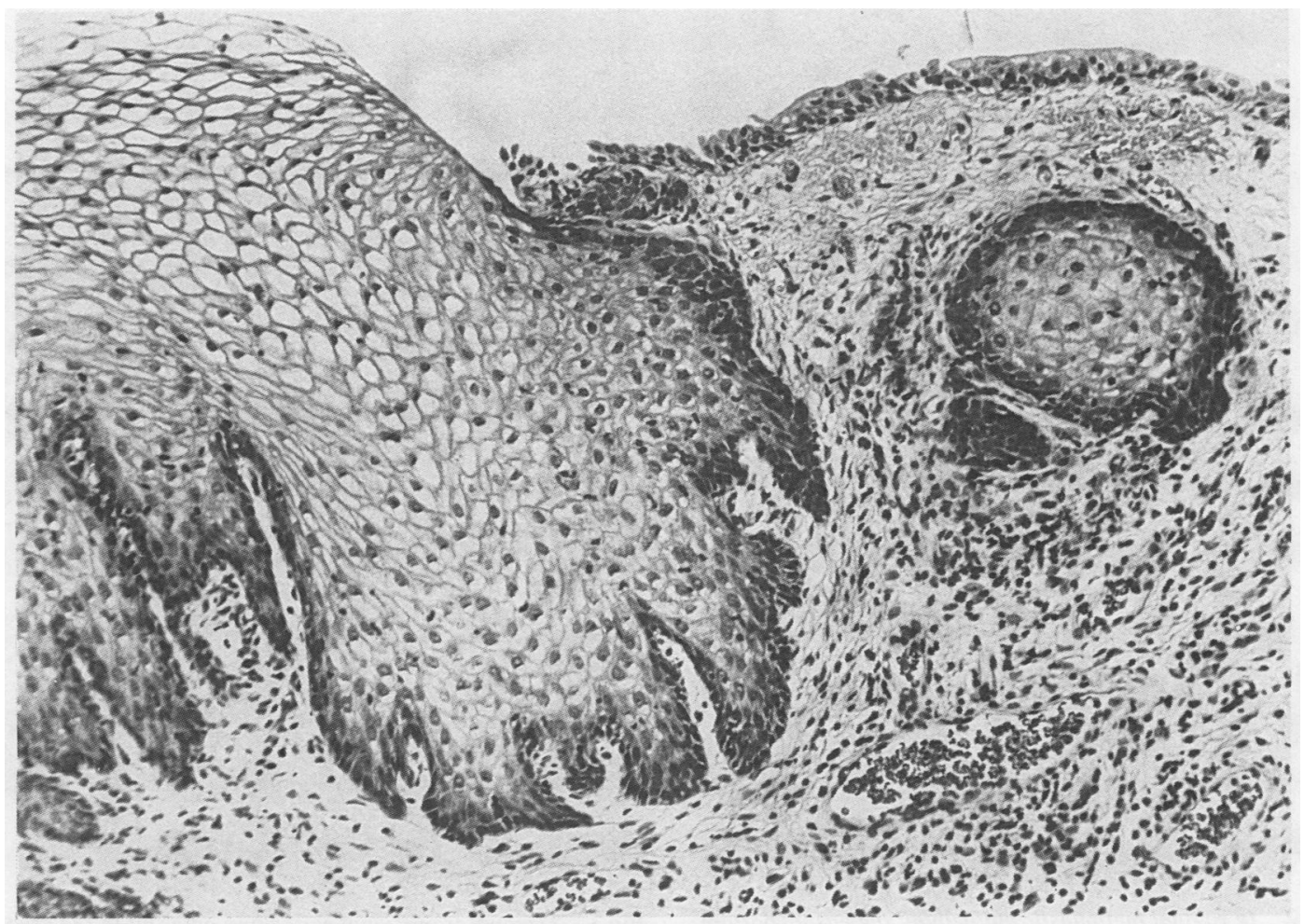

Fig 1 Squamous epithelium with cytoplasmic vacuolation overlying lamina propria showing oedema and venous dilatation, typical of pseudomembranous trigonitis (left), contrasting with normal trigonal transitional epithelium (right). (Haematoxylin and eosin.) 
Table Oestrogen receptor staining of individual cases

\begin{tabular}{|c|c|c|c|c|}
\hline \multirow[b]{2}{*}{ Case No } & \multirow[b]{2}{*}{ Age at presentation } & \multirow[b]{2}{*}{ No of biopsies } & \multicolumn{2}{|l|}{ Oestrogen receptor staining } \\
\hline & & & Vaginal metaplastic epithelium & Unaffected epithelium \\
\hline $\begin{array}{r}1 \\
2 \\
3 \\
4 \\
5 \\
6 \\
7 \\
8 \\
9 \\
10\end{array}$ & $\begin{array}{l}34 \\
35 \\
39 \\
40 \\
40 \\
68 \\
40 \\
34 \\
40 \\
41\end{array}$ & $\begin{array}{l}1 \\
2 \\
1 \\
2 \\
1 \\
3 \\
1 \\
1 \\
1 \\
1\end{array}$ & $\begin{array}{l}+ \\
+ \\
+ \\
+ \\
+ \\
+ \\
+ \\
+ \\
+ \\
+\end{array}$ & 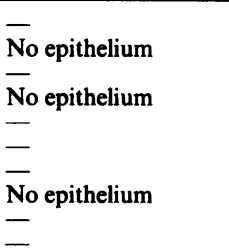 \\
\hline
\end{tabular}

confined to the nucleus in all 14 biopsy specimens (table). Within the squamous epithelium the nuclear staining was strongest in the basal and parabasal cell layers (fig 2); this distribution was similar to that seen in the control samples of vaginal squamous epithelium. In the endometrial control samples oestrogen receptor protein was demonstrable in the epithelial cell nuclei and in those of some stromal cells, a distribution which has been reported by other authors. " All nine samples of unaffected trigonal transitional epithelium showed no demonstrable oestrogen receptor protein staining in any cell layer (fig 3). Stromal, inflammatory, and endothelial cell nuclei were unstained in all samples.

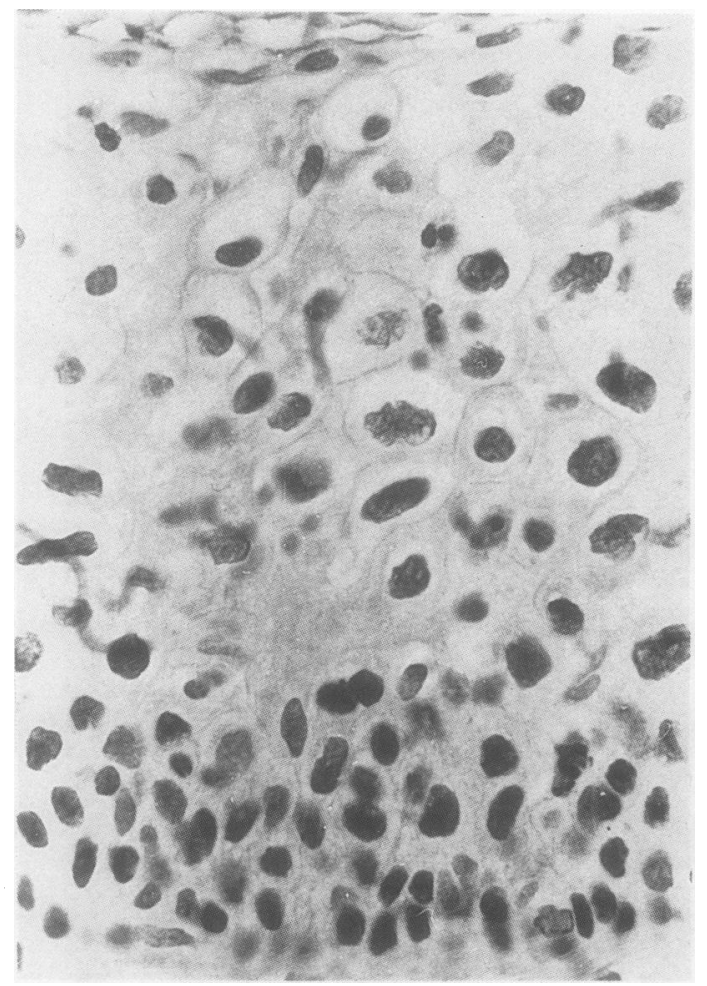

Fig 2 In vaginal metaplastic epithelium, the basal (bottom third of figure) and parabasal (middle third of figure) dark stained nuclei show oestrogen receptor protein localisation. (Immunoperoxidase photographed in blue light.)

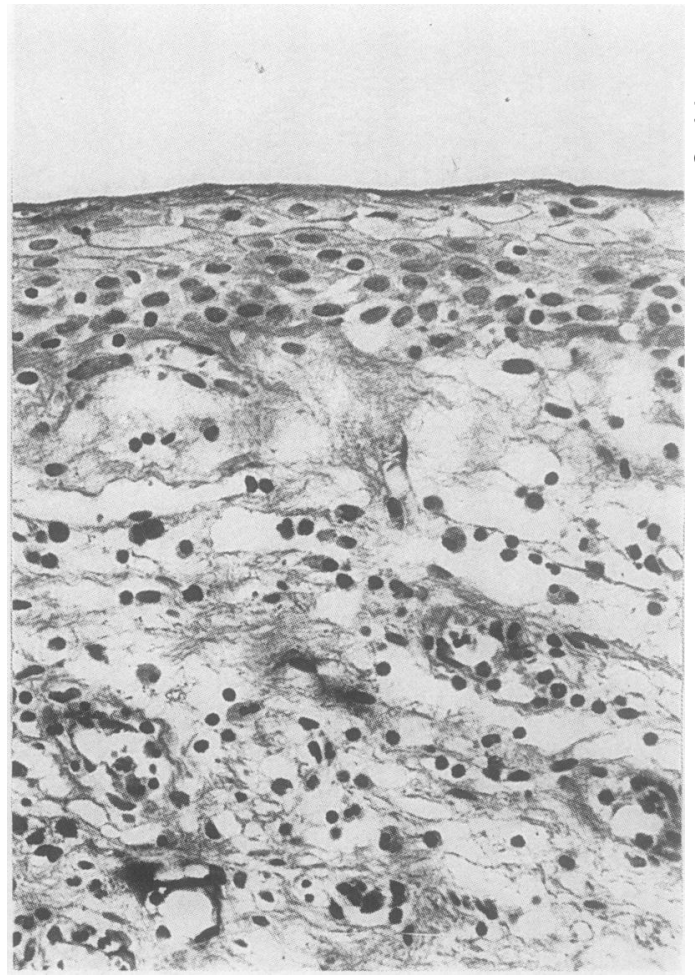

Fig 3 Trigonal transitional epithelium adjacent to the areas of vaginal metaplasia shows no nuclear staining. (Immunoperoxidase photographed in blue light.) 
Discussion

Although clinical use of the term pseudomembranous trigonitis continues because the patch of vaginal metaplasia in the trigone has some cystoscopic similarities to an inflammatory process, histologically there is neither inflammation nor a pseudomembrane. Vaginal metaplasia of the trigone is therefore a preferable pathological term.

One necropsy study documented the presence of some areas of vaginal metaplasia in the majority $(72 \%)$ of bladders, both from pre- and post-menopausal women, suggesting that the condition may often be asymptomatic. ${ }^{14}$ Most descriptions of the clinical presentation of pseudomembranous trigonitis as urethral syndrome, however, ${ }^{2-415-18}$ refer to young menstruating women with no cases before the menarche and a decreasing incidence after the menopause. The vaginal metaplasia seen by Streitz in the trigone of asymptomatic women and that noted at necropsy was unaccompanied by oedema and vascular dilatation, ${ }^{6}$ suggesting that the symptomatic lesion of pseudomembranous trigonitis may have more elements than pure vaginal metaplasia.

The age and sex data on the prevalence of this condition therefore point to a possible role for oestrogens in its aetiology. This evidence is further supported by the report by Tyler of cyclical changes in the trigonal epithelium correlated with phase of the menstrual cycle, paralleling those seen in vaginal epithelium $^{8}$ and by Streitz of exacerbation of the changes caused by oestrogen administration. ${ }^{6}$ Furthermore, there is experimental evidence for induction of vaginal metaplasia of the trigone by oestrogens in animals. ${ }^{19}$ The case of vaginal metaplasia of the trigone in a man receiving oestrogens ${ }^{1}$ and the description of squamous metaplasia of the prostatic ducts associated with oestrogen therapy ${ }^{8}$ indicate that even in men the trigonal epithelium responds to this hormone.

The presence of nuclear oestrogen receptor demonstrable by either radioligand ${ }^{8}$ or immunohistochemical methods" has been shown to correlate with ability of the tissues to respond to oestrogens. ${ }^{20}$ The nuclear uptake of oestrogen against a concentration gradient ${ }^{21}{ }^{22}$ has been shown to be due to the presence of a specific oestrogen receptor protein-the formation of a complex between this protein and oestradiol being central to the mechanism of oestrogen action. ${ }^{23}$ Demonstration of nuclear oestrogen receptor protein in archival tissues has recently been made possible by the availability of specific anti-oestrogen receptor monoclonal antibodies ${ }^{101213}$ used in our sensitive immunohistochemical technique. Our demonstration, for the first time, of nuclear oestrogen receptor protein confined to trigonal epithelium showing vaginal meta- plasia, in a distribution similar to that reported in normal vaginal squamous epithelium, ${ }^{1}$ adds important supporting evidence for an oestrogen mediated aetiology in this condition.

The restriction of the lesion to the trigone would suggest that the trigone may have an embryological derivation distinct from the remainder of the bladder. The embryology of the trigone is disputed, ${ }^{24-26}$ although this area may be mesodermal in origin; the rest of the bladder is endodermal. ${ }^{27}$ The current consensus of opinion suggests that the trigone is derived by widening and being incorporated into the posterior wall of the urogenital sinus of the terminal segment of the conjoining mesonephric duct and developing ureter. ${ }^{28}$ For this reason, the trigone, like the mesonephric ducts, is mesodermal while the remainder of the bladder is endodermal having been derived from the urogenital sinus. The vagina is derived from the Mullerian ducts and urogenital sinus. ${ }^{25}$ Development of the trigone from the Mullerian system would explain the oestrogen receptor content and capacity of the epithelium to respond to oestrogens, but we know of no direct proof of such derivation. During development, however, the Mullerian and Wolffian ducts are apposed, lying within the same connective tissue sheath. $^{29}$ Rarely, they may be contiguous ${ }^{8}$ and anomalous vaginal insertion into the bladder has been reported. ${ }^{30}$ Thus it is possible for a Mullerian component to contribute to the trigone.

Our demonstration of nuclear oestrogen receptor confined to areas of trigonal epithelium showing vaginal metaplasia is an important further link in proving the capacity of such epithelium to respond to oestrogens. We cannot determine, however, whether this expression of oestrogen receptor protein is causal in development of vaginal metaplasia or merely a covariable induced by some other histological stimulus. We did not show the presence of oestrogen receptor in the nuclei of endothelial cells in the lamina propria in this condition. The vasodilatation and oedema which, together with vaginal metaplasia, constitute the full lesion of pseudomembranous trigonitis, remain unexplained.

Dr D D Giri was supported during this project by a Commonwealth Medical Research Scholarship.

D75 and D547 antibodies were a kind gift of Dr G L Greene, Ben May Cancer Research Laboratories, Chicago, Illinois.

\section{References}

1 Henry L, Fox M. Histological findings in pseudomembranous trigonitis. J Clin Pathol 1971;24:605-8.

2 Heymann A. Die cystitis trigoni der Frau. Zentralblatt für die Krankleiten der Hahn und Sexual Organe 1905;16:422-33.

3 Ryall EC. Pseudomembranous trigonitis. Br J Urol 1929;1:254-7. 
4 Clarke BG, Gherardi GJ. Urethrotrigonitis or epidermidization of the trigone of the bladder. J Urol 1962;87:545-8.

5 Widran J, Sanchez R, Gruhn J. Squamous metaplasia of the bladder; a study of 450 patients. $J$ Urol 1974;112:319-25.

6 Streitz JM. Squamous epithelium in the female trigone and urethra. J Urol 1963;90:62-6.

7 Packham DA. The epithelial lining of the female trigone and urethra. Br J Urol 1971;43:201-5.

8 Tyler DE. Stratified squamous epithelium in the vesical trigone and urethra; findings correlated with the menstrual cycle and age. Am J Anat 1962;111:319-25.

9 Tchernichin A, Tseng L, Strumpf WE, Gurpide E. Radio-autographic study of human endometrium superfused with estradiol-17 beta, estrone, estriol and progesterone. J Steroid Biochem 1973; 4:451-5.

10 King WJ, Greene GL. Monoclonal antibodies localise oestrogen receptor in nuclei of target cells. Nature 1984;307:745-7.

11 Press MF, Nousec-Goebl NA, Bur M, Greene GL. Estrogen receptor localisation in the female genital tract. Am J Pathol 1986;123:280-92.

12 Greene GL, Nolan C, Engler JP, Jensen EV. Monoclonal antibodies to human estrogen receptor. Proc Natl Acad Sci USA 1980;77:5115-9.

13 Miller LS, Tribby IIE, Miles MR, Tomita JT, Nolan C. Hybridomas producing monoclonal antibodies to human estrogen receptor. Fed Proc 1982;41:520.

14 Long ED, Shepherd RT. The incidence and significance of vaginal metaplasia of the bladder trigone in adult women. $\mathrm{Br} \mathrm{J}$ Urol 1983;55:189-94.

15 Orr L. Chronic pseudomembranous trigonitis. South Med J 1933; 26:359-61.

16 Fowler HA. Pseudomembranous trigonitis with observations on bladder dysfunction in the female. Urologic and Cutaneous Review 1936;40:156-63.

17 Cifuentes L. Epithelium of vaginal type in the female trigone. J Urol 1947;57:1028-37.

18 Ney C, Ehrlich JC. Squamous epithelium in the trigone of the human female urinary bladder. J Urol 1955;73:809-19.
19 Burns RK Jr. Origin and differentiation of epithelium of the urogenital sinus in the opossum. Proc Soc Exp Biol 1941;47: 106-8.

20 Press MF, Green GL. An immunocytochemical method for demonstrating estrogen receptor in human uterus using monoclonal antibodies to human estrophilin. Lab Invest 1984;50: 480-6.

21 Jensen EV, Suzuki T, Kawashima T, Strumpf WE, Jungblut PW, DeSombre ER. A two step mechanism for the interaction of estradiol with rat uterus. Proc Natl Acad Sci USA 1968;59: 632-8.

22 Gorski J, Toft D, Shymata G, Smith D, Notides A. Hormone receptors: Studies on the interaction of estrogen with the uterus. Recent Prog Horm Res 1968;29:45-80.

23 Underwood JCE, Dangerfield VJM, Parsons MA. Oestrogen receptor assay of cryostat sections of human breast carcinomas with simultaneous quantitative histology. J Clin Pathol 1983; 36:399-405.

24 Beck F, Moffat DB, Davies DP. The Bladder and urethra. In: Human embryology. 2nd ed. Oxford: Blackwell Scientific Publications, 1985:254-5.

25 Moore KL. Clinically oriented anatomy. 2nd ed. Baltimore: Williams, Wilkins \& Co, 1985.

26 Moore KL. The urinary bladder. In: The developing human. 4th ed. Philadelphia: WB Saunders \& Co, 1988:257-8.

27 Brockis JG. The development of the trigone of the bladder with a report of a case of ectopic ureter. Br J Urol 1952;24:192-200.

28 Young BW. Lower urinary tract obstruction in childhood. Philadelphia: Lea and Febiger, 1972:15-9.

29 Gruenwald P. Relation of growing Mullerian duct to Wolffian duct and its importance for genesis of malformations. Anat Rec 1941;81:1-19.

30 Weiss JM, Dykhuizen RF. An anomalous vaginal insertion into the bladder. J Urol 1967;98:610-2.

Requests for reprints to: Dr T J Stephenson, Department of Pathology, University of Sheffield Medical School, Beech Hill Road, Sheffield S10 2RX, England. 